University of Warwick institutional repository: http://go.warwick.ac.uk/wrap This paper is made available online in accordance with publisher policies. Please scroll down to view the document itself. Please refer to the repository record for this item and our policy information available from the repository home page for further information.

To see the final version of this paper please visit the publisher's website. Access to the published version may require a subscription.

Author(s): Michael Orton and Peter Ratcliffe

Article Title: New Labour Ambiguity, or Neo-liberal Consistency? The Debate About Racial Inequality in Employment and the Use of Contract Compliance

Year of publication: 2005

Link to published version:

http://dx.doi.org/10.1017/S0047279404008578

Publisher statement: None 


\title{
New Labour Ambiguity, or Neo-liberal Consistency? The Debate About Racial Inequality in Employment and the Use of Contract Compliance
}

\author{
MICHAEL ORTON* and PETER RATCLIFFE** \\ *Institute for Employment Research, University of Warwick, Coventry CV4 7AL \\ email: Michael.Orton@warwick.ac.uk. \\ **Department of Sociology, University of Warwick, Coventry CV4 7AL \\ email: Peter.Ratcliffe@warwick.ac.uk
}

\begin{abstract}
In 2003 the UK government set an objective that in ten years' time Britain's minority ethnic groups should not face disproportionate barriers in the labour market. A key 'barrier' is discrimination by employers. This article examines one potential way forward: the use of contract compliance. First, the article presents findings from the authors' study of an innovative use of contract compliance by a group of local authorities in the West Midlands. If contract compliance can be made to work and New Labour is committed to addressing racial inequality in employment, this suggests that contract compliance is an approach that the government should be seeking to develop. The second part of the article therefore considers New Labour's stance on contract compliance, which can be seen to be highly ambiguous. It is argued that if contract compliance is located within the broader context of New Labour policy development, what is apparent is that the professed aspiration for social change is compromised by a dominant commitment to the maintenance of neo-liberal economic policies. The conclusion is that it is likely that only limited progress will be made in achieving racial equality in employment.
\end{abstract}

\section{Introduction}

The fundamental concern of this article is with redressing racial inequality in employment in the UK, particularly in the context of the commitment made in 2003 by the government that 'In ten years time, ethnic minority groups living in Britain should no longer face disproportionate barriers to accessing and realising opportunities for achievement in the labour market' (Cabinet Office, 2003: 8). While this may not be a commitment to ensuring racial equality in employment, there is a clear implication that, by 2013, employers will no longer discriminate on the basis of 'race', ethnicity or national origin.

The focus of the article is on addressing racial inequality in employment through the use of contract compliance, in particular drawing on research by the authors (Orton and Ratcliffe, 2003, 2004) evaluating an innovative use of 
local government procurement known as the West Midlands Common Standard (WMCS). The term 'contract compliance' originated in the US and is commonly used to describe procedures adopted by public sector organisations to ensure that companies to which they give contracts have an equal opportunities policy (Fee, 2002). In the US, contract compliance has been the subject of extensive debate from its introduction in the 1940 s using an equal opportunities approach, through to affirmative action, calls for a new 'economic empowerment model' (Wallace, 1999) and questions as to the effectiveness of contract compliance (see Pinkney, 1984; Taylor, 1991; Herring and Collins, 1995; Jackson, 1995; Ratcliffe, 2004). Erridge and Fee (1999) characterise the debate about contract compliance as on the one hand being about identifying labour costs and benefits, and the impact on competitiveness, balanced against ethical and moral arguments. Certainly the concern with cost is an important one including issues around affirmative action priorities leading to failings in public procurement, and is one reason why, although contract compliance in the US is generally considered to have been an effective policy instrument (Fee, 2002), this is not unreservedly so and there has been a retreat from its use (Ratcliffe, 2004).

In the UK the use of contract compliance has been much more limited, but there is still considerable debate about its role (for example, Fee, 2002; Erridge and McIlroy, 2002; Erridge and Fee, 1999; Fee et al., 1998; Erridge and Murray, 1998). A particular concern is that in the UK there is uncertainty as to what is permitted under national and European Union (EU) legislation. Indeed, the complexity of the available legal framework has been characterised as a 'double jeopardy', meaning that if action is not prevented by UK law then it may well be prohibited by EU regulations (Fee et al., 1998). Yet this is an area of considerable current policy development, with drivers for change including the Race Relations (Amendment) Act 2000, the introduction of the Best Value regime, a major review of local government procurement, commonly referred to as the 'Byatt Review' (Department for Transport, Local Government and the Regions [DTLR], 2001a) and even the Human Rights Act.

The importance of the evaluation of the WMCS, on which this article draws, is four-fold. It first illustrates the way that the available legal space can be used effectively to implement a contract compliance policy, even within the constraints of UK and EU procurement legislation, and highlights how contract compliance can be incorporated within procurement procedures so as to avoid the failings referred to above. Second, it allows for examination of the effectiveness of the approach, including whether the adoption of an equal opportunities policy goes beyond procedural concerns and actually impacts, in this case, on the employment opportunities of minority ethnic groups. Third, while there are current examples of the use of contract compliance such as in Northern Ireland (see Fee, 2002) the WMCS provides an example of contract compliance within UK local government, and also contract compliance being used with the specific 
aim of addressing racial inequality in employment. There is also evidence that the WMCS is attracting interest from other authorities as a potential model to adopt (Orton and Ratcliffe, 2003, 2004). Fourth, the focus on racial inequality and local government procurement connects the example of the WMCS with the broader policy development taking place at national level and allows for a critical examination of New Labour policy on contract compliance in relation to its commitment regarding racial inequality in employment.

The article will begin by contextualising the WMCS within current debates about racial inequality in employment, the use of equal opportunities policies, an examination of what exactly is meant by contract compliance, and a more detailed discussion of local government procurement. We will then present key findings from the evaluation of the WMCS. In the light of the research the issue that arises is that if contract compliance appears to offer potential for redressing racial inequality in employment, and New Labour is committed to this aim, this suggests that contract compliance is an approach that the government should be seeking to develop. The article therefore asks whether this is the case. To address this question we examine New Labour policy development both on racial inequality in employment and on local government procurement. As with other areas of New Labour policy, what is revealed is considerable ambiguity in the government's approach to contract compliance. The article then seeks to make sense of this ambiguity within the context of broader tensions in New Labour's approach to racial equality, a fundamental tension between the use of contract compliance and a concern with fiscal restraint and control of public spending and the importance of New Labour's commitment to labour market flexibility. This leads to a discussion of whether New Labour's approach is ambiguous, or merely reflects a consistency of commitment to neo-liberal economic policies. The article concludes by considering the implications for the achievement of racial equality in employment. It is racial equality in employment that is also the starting point for our discussion.

\section{Racial inequality in employment in the UK}

In empirical terms, racial inequality is a well-documented feature of the UK labour market. The government's commitment regarding racial inequality in employment, which has already been discussed, was made as part of a series of reports on ethnic minorities and the labour market produced by the Cabinet Office, principally a detailed Analytical Report which reviewed relevant evidence (Cabinet Office, 2002) and a Final Report setting out policy recommendations (Cabinet Office, 2003). These reports highlighted the extent of racial inequality in employment, as have other recent studies (for example, Twomey, 2001; Berthoud, 2002; Mason, 2003). For some time there has been evidence of divergence in the circumstances of the principal minority ethnic groups, and between men and 
women within those groups (for example, see Modood et al., 1997), but in overall terms the unemployment rate for people from minority ethnic groups is often at least twice the rate for white people and can be three times higher (Mason, 2003). In terms of work, there is a discernible tendency for different minority ethnic groups to be concentrated in distinct economic sectors, and the range of occupations is more restricted than for white people (Modood et al., 1997; Mason, 2003).

In explaining these patterns, studies have considered a wide range of contributory factors - such as lack of English language skills, qualification deficits and geographical location - but discrimination remains a key issue. For example, when such variables are controlled for:

there remains a residue of disadvantage and exclusion that cannot be so easily explained. As a result, it is difficult to avoid the conclusion that, despite 35 years of 'race relations' legislation, discrimination continues to play a significant part in the labour market placement of minority ethnic groups. (Mason, 2003: 80)

Tackling racial inequality in employment is therefore not just about increasing the human capital of ethnic minorities but is about confronting discrimination, and contract compliance offers one possible way forward. We have already noted that contract compliance is commonly used to describe procedures to ensure that private sector companies awarded government contracts have an equal opportunities policy (EOP). Before looking in more detail at contract compliance let us first consider the role of EOPs in redressing racial inequality in employment.

\section{Racial inequality in employment and equal opportunities policies}

The use and effectiveness of EOPs has been the subject of wide-ranging debate (for example, see Osborne, 2003; Harris, 2000; Phillips, 1999). For our purposes, what is important is not discussion of the philosophical issues involved, but the recognition of EOPs as a tangible means of addressing inequality. For example, the Commission for Racial Equality (CRE) has actively promoted the adoption of EOPs covering key elements such as open recruitment methods, monitoring the ethnic origin of job applicants and employees, and taking positive action to remedy under-representation. Added weight was given by the Commission on the Future of Multi-Ethnic Britain (known as The Parekh Report), which recommended that the government should place a statutory duty on all employers to create and implement an EOP (Runnymede Trust, 2000).

It is, however, important to recognise that, even with the adoption of an EOP, procedures can be manipulated so an effective EOP also requires the monitoring of outcomes. Indeed, studies of EOPs in the UK in the 1980s (for example Jewson and Mason, 1989; Jenkins, 1989) found there to be ambiguity as to aims and objectives, particularly as to whether their primary function was to ensure 
procedural fairness or to redress under-representation (also see Osborne, 2003). The 'radical' model of equal opportunities to which Jewson and Mason (1989) allude deploys quotas so as to ensure adequate representation of minorities. This approach is legal in the US under affirmative action law but in the UK legislation permits only a 'liberal' model (ibid.), meaning that employers can set targets (but not quotas), and then use positive action to help meet those targets. But even when restricted to this 'means-led' approach, there is much evidence to suggest that the removal of (illegitimate) constraining forces has the potential to impact positively on employment distributions (Mason, 2003; Ratcliffe, 2004). However, the issue of procedural fairness versus monitoring outcomes is a key point to which we return below. But let us now turn to a more detailed consideration of contract compliance and local government procurement.

\section{Contract compliance and local government procurement Contract compliance}

Thus far we have described contract compliance only generally, so let us now examine what exactly is meant by the term. Contract compliance refers to the use of public sector procurement - that is, contracts awarded by public bodies to third parties - to achieve wider social and economic goals (Fee, 2002). Procurement in relation to local government will be discussed below, but the important point to make at this stage regarding contract compliance is that there are different models and approaches. In particular, a distinction, which to a certain extent reflects the discussion of EOPs above, can be made between an affirmative action model, which, as we have seen, can be used in the US, and potentially weaker models that focus on requiring contractors to have an EOP (for a discussion see Fee, 2002). In the UK, the affirmative action approach is not permitted (Ratcliffe, 2004) so it is the equal opportunities approach that must be pursued.

As already noted, the legal framework for contract compliance within the UK is highly complex, also being subject to EU regulations. The latter have been discussed in detail elsewhere (Cormack and Niessen, 2002; Fee, 2002; Martin et al., 1999). In short, there is a series of EU directives on procurement based on an economic rationale which aims to create competitive conditions in which public contracts can be awarded without discrimination between companies from different member states, and within which the use of social criteria as part of the procurement process, while not precluded, is limited (Fee, 2002). However, it has been argued that it is not the detail of what the regulations say, but the perception that they hinder the use of contract compliance, that is the more important point (DTLR, 2001a). Within the UK there is also a specific legal framework relating to local authorities, so let us now consider further local government procurement. 


\section{Local government procurement}

The government's review of local authority procurement adopted a broad definition encompassing the whole process of acquisitions including the purchase of goods, the commissioning of services (often used in the context of social services) and the procurement of works such as building projects (DTLR, 2001a). Procurement therefore includes local authority contracts awarded, primarily to private sector companies, for anything ranging from basic items of stationery to multi-million pound contracts for the provision of social care and construction work. The extent, and significance to the wider labour market, of local government procurement should not be under-estimated. Total nonpay revenue expenditure by local authorities in England stands at $\mathfrak{E}_{42.2}$ billion,

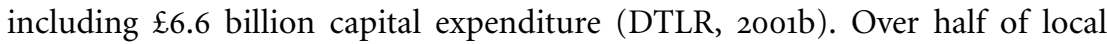
government spending is now on contracts (Cabinet Office, 2003).

In the 1980 s the use of contract compliance by local authorities - the best-known example perhaps being the Greater London Council - was severely restricted by the Local Government Act 1988. This on the one hand introduced Compulsory Competitive Tendering (CCT), imposing a legal obligation on local authorities to put certain services out to competitive tender, and at the same time made it illegal for councils to entertain any 'non-commercial considerations', including equal opportunities, in awarding contracts. The key exception was that the Secretary of State approved six questions which councils could ask potential contractors regarding racial equality in employment. While the six questions were ostensibly rather limited in scope, councils were allowed to ask firms to supply documents in support of their responses, thereby providing the opportunity to request a copy of a company's racial equality policy/EOP. As will be seen below, the six questions remain in place today, but the policy context is changing rapidly with the Best Value regime. Best Value, which will be discussed in more detail below, is the framework within which local authorities have to make service provision choices (see Martin and Davis, 2001). Best Value does not mean a neglect of what can be seen as an emphasis on competition in procurement and value for money (Erridge and McIlroy, 2002), but it does allow for a more legitimate inclusion of equalities' issues in procurement (Erridge and Murray, 1998).

Having identified a number of key issues around different models of contract compliance, the complexity of the legal framework in the UK, the question of cost, and the effectiveness of EOPs, we now turn to the specific example of the WMCS.

\section{Contract compliance in practice: the West Midlands Common Standard (WMCS)}

The WMCS has previously been discussed in detail (Orton and Ratcliffe, 2003, 2004), so we present here a summary of key points. The WMCS was 
developed by six councils in the West Midlands - Birmingham, Coventry, Sandwell, Redditch, Walsall and Wolverhampton - working together as the 'West Midlands Forum', and in conjunction with the CRE. All six councils had since the introduction of the Local Government Act 1988 used the six questions, but the CRE wanted to explore whether their use could be developed further and therefore suggested that the councils work together to implement a 'Common Standard' for their contractors regarding racial equality.

Contract compliance can be implemented at different points in the procurement process (Erridge and McIlroy, 2002) and the WMCS is based on what is described as the 'pre-qualification' stage. This relies on the councils having 'standing lists' of approved contractors. A standing list is a database of firms who have expressed interest in tendering for work from the council, and have been assessed by the council as being suitable to do so. Typically, a firm that contacts a council will be asked to complete a pre-qualification questionnaire probing such matters as the company's technical competence and financial soundness. Each of the councils involved in the West Midlands initiative has a standing list of several hundred companies. While the raison d'etre for such a list may be the desire to minimise the possibility of contracting unsuitably qualified or financially dubious firms, it also provides the scope for other criteria to be considered, including racial equality.

The focus on the pre-qualification stage has a number of advantages. It means that the councils ensure that all potential contractors, not just those awarded contracts, have an EOP thereby impacting on a larger number of firms. It also means that having an EOP is not the determining factor at award of contract stage (although there could be examples such as the provision of care for Asian elders where equalities' issues would be central to the specific tender), thereby addressing concerns referred to above about affirmative action policies leading to failings in procurement decisions. A further advantage of the WMCS regarding cost is that working on a regional basis enables the councils to share expertise, good practice and resources, as well as providing a greater incentive for contractors to comply. The whole WMCS approach is very much about 'mainstreaming' contract compliance within the procurement process.

The actual requirements of the WMCS follow the equal opportunities model of contract compliance discussed above. Using the CRE Code of Practice in Employment as a starting point, the WMCS sets various criteria that firms must meet (for example, open recruitment), with having an EOP of central importance. A key factor is that a detailed assessment of a firm's EOP is undertaken to ensure that EOPs meet the set criteria. The WMCS also includes initiatives aimed at addressing the issue of moving beyond simple procedural requirements to monitoring impact on the employment of minority ethnic groups. Thus, the WMCS includes a three-yearly review of companies' EOPs. In addition, there is a system of contract monitoring. This involves meeting with contracted 
companies to examine whether formal, written policies are actually being implemented.

The Common Standard was launched in 1998 and by 2001 over two and a half thousand companies had been assessed. It was at this stage that the evaluation took place.

\section{The evaluation}

The evaluation included some analysis of the WMCS database but was principally based on in-depth interviews with 33 people drawn from 24 different contractors. The aim was to provide case studies of how contractors have responded to the introduction of the WMCS. Sampling was guided by the need to generate a range of companies of different sizes and in different sectors, reflecting in broad terms the variety of companies on the WMCS database. There was an even split between companies that essentially did work only in the West Midlands and those that covered a larger part of the country, or worked nation-wide. The companies ranged from one with just eleven employees to another which forms part of one of the top twenty largest companies in the US. The interviews with companies allowed for examination of the themes identified in the opening discussion regarding the adoption of EOP procedures and the monitoring of outcomes. These points will now be considered in turn.

The WMCS was found to have had a significant impact on encouraging firms to adopt EOPs. Some companies had never before had an EOP and the introduction of the WMCS meant that for the first time these companies were engaging with equalities' issues and addressing how to ensure their employment practices promoted equality of opportunity. In such cases, the impact of the WMCS was dramatic. Other companies had formerly relied on an equal opportunities statement expressing their commitment to the principle of equality. There is, of course, a significant difference between a statement of commitment to racial equality and the introduction of a formal policy and procedures to achieve that end. Implementation of the WMCS meant companies had to develop such a strategy. Once again the impact of the WMCS initiative was immediate. A third group of companies already had an EOP in place. But, even here, the WMCS had an impact in that it encouraged firms to review, update and revise policies, for example addressing areas of weakness such as the failure to monitor workforce composition.

With regard to policy implementation, the evaluation also found a broad range of generally positive responses. The research provided examples of companies making great progress on equal opportunities: for example, through the provision of training on equalities' issues, the development of more formalised recruitment practices and even the adoption of positive action strategies. There 
were, however, isolated examples of companies which claimed to be taking no steps at all to implement their policy. Closer examination revealed that this was not quite true: they had, for example, circulated the new policy to staff and stated in job advertisements that the company was an equal opportunities employer. For firms that had not previously engaged with equalities' issues, even such small steps represented clear progress.

Recognising, as discussed above, that procedures can be manipulated and an effective EOP also requires the monitoring of outcomes, the evaluation considered the question of whether the introduction of the WMCS had already had a discernible impact on minority ethnic employment. In order to assess this, ethnic monitoring by companies would need to be widespread, but the research found this not to be the case. Only one company could provide evidence of an annual monitoring exercise being undertaken. In small companies, managers were able during the course of the research interview to list their employees from memory, and cite the number from minority ethnic groups. But the absence of systematic monitoring meant there was no real sense of how the composition of a company's workforce was changing over time and whether under-representation of minorities was being redressed.

In order to address this, there is a need to be more explicit about the aims of the WMCS. As already noted, EOPs in the UK are based on a liberal rather than radical approach. Although restricted to this means-led approach, however, it is vital to make it clear to companies that redressing the under-representation of minorities (applying this to our example) is the principal objective of the WMCS. Doing so would allow councils to prioritise the need for companies to undertake formal ethnic monitoring. As we have seen, the councils already have the 'tools' to do this, in the form of the three-yearly review of companies' EOPs and by contract monitoring. The WMCS database could then be used to measure change over time in the ethnic make-up of the overall workforce. However, it remains the case that without active ethnic monitoring gains may be limited. So our conclusion, as previously argued (Orton and Ratcliffe, 2003, 2004), is that this example of using public procurement at the local level to address racial inequality in employment is working in a number of clearly identifiable ways, and with further development offers a potential means of redressing racial inequality in employment.

If contract compliance can be made to work and New Labour is committed to addressing racial inequality in employment, this suggests that it is an approach that the government should be seeking to develop. But is this the case? To address this question we will now consider New Labour policy development on racial inequality in employment and on local government procurement, including the Race Relations (Amendment) Act 2000. We will begin with the Cabinet Office reports on ethnic minority participation in the labour market, referred to above. 


\section{New Labour, racial inequality in employment and contract compliance}

The Cabinet Office Reports on ethnic minorities and the labour market

The Cabinet Office Analytical Report (Cabinet Office, 2002) constitutes an extensive review of evidence on racial inequality in the labour market, in which discrimination is identified as a significant issue and contract compliance a possible response. The Final Report (Cabinet Office, 2003) builds on this, setting out policy options and recommendations. These once again include specific reference to contract compliance, but with some significant ambiguity. The Final Report describes the US as an example of the effective use of procurement to promote racial inequality in employment, and cites the WMCS (the subject of our study) as an example of good practice. But ambiguity and tension then arises because the report cites a series of reasons why using procurement to pursue racial equality may be considered problematic:

- there may be regulatory burdens and costs;

- there is a risk of discouraging potential bidders;

- UK and EU law is so complex on this issue that there is a danger of authorities adopting an approach that is unlawful; and

- contract compliance might confuse judgements about value for money. (ibid: 137)

The evidence demonstrating that contract compliance works as an effective means of prompting private sector companies to adopt EOPs therefore stands in tension with concern about potentially 'negative' impacts, of which the issue of cost appears most significant. While this may in some ways reflect Erridge and Fee's (1999) characterisation of the debate about contract compliance being about costs and competitiveness versus ethical and moral arguments, the recommendation of the Final Report is far from a ringing endorsement of the use of contract compliance. Rather, the recommendation is something of a damp squib, simply stating that there is a clear case for guidance to set out the benefits and to mitigate the risks associated with taking account of social objectives in public procurement' (ibid.). There is certainly a failure to take a definitive position and require rather than merely encourage public bodies to address equality issues through procurement.

If we now turn to consider policy development on local government procurement (as opposed to racial inequality in employment), further ambiguity emerges.

\section{Policy development on local government procurement}

In examining policy development on local government procurement, there are two main areas to consider: the Byatt review of local government procurement (DTLR, 2001a); and new guidance for local authorities on the use of contract 
compliance. We will consider these in turn, before considering a further key policy development: the Race Relations (Amendment) Act $2000[\mathrm{RR}(\mathrm{A}) \mathrm{A}]$, which brings together concerns regarding racial inequality and local government procurement.

\section{The Byatt review of local government procurement}

The Byatt review provided a wide-ranging examination of local government procurement with extensive recommendations for change, but gave scant consideration to contract compliance, and even then the picture conveyed was far from positive. The review acknowledged the statutory duty on local authorities to promote good 'race relations', imposed by the RR(A)A, but did not make specific reference to racial equality in employment as a possible aim of procurement policy. More generally, the report stated that procurement can be used to achieve an authority's wider social objectives (that is, those that are not financially or performance based), but immediately undermined this argument by adding a number of riders including:

- where a policy involves additional expenditure, specific costings should be included so local citizens can understand what is being done on their behalf;

- distorting the procurement process to favour specific suppliers will often have a cost to the community as a whole which is disproportionate to the benefits derived by a small number of people. (ibid: 35 )

So, as in the Cabinet Office Final Report, the issue of cost is highlighted. But even more than this, the Byatt Report also included an argument that casts some doubt on the use of procurement for social objectives at all, placing a greater emphasis on the free market to serve the interests of local communities:

Longer-term benefits to the local community are usually best served by using procurement to achieve value for money and to support an open and competitive local economy. (ibid.)

This betrays adherence to an extremely naïve view of the local economy as essentially fair, 'open' and 'competitive'. Were this to be the case, there would have been no need for the government's 'commitment' to redressing discriminatory employment practices over the coming decade nor for that matter the RR(A)A. Byatt gives minimal consideration to the use of procurement to promote racial equality in employment, accords a prominent place to the issue of cost and questions the fundamental merit of contract compliance.

\section{Best Value and equal opportunities}

This sense of ambiguity about contract compliance is further illustrated by a closer look at procurement from the perspective of Best Value policy development. As we have seen, the West Midlands initiative was based on the use of the six questions provided for in the Local Government Act 1988, which legislated for 
CCT. The Local Government Act 1999 replaced CCT with Best Value, which ostensibly aims to provide greater scope for consideration of local service delivery and a broader definition of 'value for money'. Confusingly, the 1999 Act repealed sections of the 1988 Act relating to CCT but did not repeal the section prohibiting the use of non-commercial considerations. Because Best Value aimed at a broader approach than CCT, this caused confusion within local government as to what exactly was permissible. To address this confusion, in 2001 the government made an order in the form of a Statutory Instrument (The Local Government Best Value (Exclusion of Non-commercial Considerations) Order 2001-SI 2001 No. 909), which has subsequently been included in a new Circular containing statutory guidance on related issues, such as the 'two-tier workforce' which deals with local authority staff transferred to a new service provider (Office of the Deputy Prime Minister, 2003).

The guidance makes clear that equal opportunities can be given much greater consideration under Best Value than was the case with CCT. The guidance states that 'Best value authorities may take account of the practices of potential service providers in respect of equal opportunities (such as race, gender, disability, religion, age, and sexual orientation)', extending considerably the areas of discrimination that can be taken into account (ibid: 44). Also, while authorities 'will continue to be able to ask the six questions ... they are no longer restricted to these six questions as the sole means of taking account of racial equality. In addition, and where relevant to the contract, and for the purposes of achieving best value, the authority will be able to ask some further questions in relation to racial equality' (ibid: 45 ). There is now clearly scope for authorities to transcend the limitations of the 1988 Act and do a great deal more.

While this development is to be welcomed, its impact is immediately limited by a number of further factors because, as with the previous examples of policy development, the guidance places riders on the potential use of contract compliance. First, unlike the 1988 Act, which specified questions that local authorities could ask, this is not the case with Best Value. This creates a strong sense of uncertainty among local authorities as to exactly what is permissible. Second, while it is stated that equal opportunities can be considered in prequalification questionnaires, the main thrust of the guidance is in stressing that equal opportunities must be 'relevant' to a specific contract (as indicated by the above quotation). The phrase 'where relevant to the contract' appears repeatedly, giving a strong suggestion that the consideration of equal opportunities is about service delivery and not about ensuring that contractors have an EOP encompassing human resource matters. Third, while the importance of equal opportunities considerations is acknowledged, a further recurring theme is that a balance needs to be struck with other considerations, and authorities must 'avoid making requests for information that are disproportionate . . . and not strictly relevant to the contract' (ibid.). 
For authorities committed to using procurement to promote equal opportunities, there is undoubtedly greater scope to do so. However, it is far from clear how best to proceed, and individual authorities are left to form their own view as to what the law allows them to do and where the right 'balance' is to be struck. Critically, there is no direct requirement that authorities consider the use of contract compliance, and the impact is therefore likely to be limited. The guidance aims to remove ambiguity regarding the use of procurement to pursue social objectives. However, the irony is that it is ambiguity itself that remains the key theme.

\section{The Race Relations (Amendment) Act 2000}

The tensions and ambiguities we have discussed are perhaps most explicit in guidance supporting the $\mathrm{RR}(\mathrm{A}) \mathrm{A}$, the provisions of which came into effect in 2002. The new legislation places on each public authority (with only limited exceptions) a statutory duty to eliminate unlawful racial discrimination and promote equality of opportunity.

Procurement is a function to which the statutory duty applies, and, while an authority cannot delegate to a private sector company the authority's responsibilities under the Act, the contractor is acting on behalf of the authority and it is the authority that will be held responsible if the contractor (say) was found to be guilty of racial discrimination while working on a council contract. This would appear to provide the opportunity for a step change in the use of contract compliance, especially as there is a specific obligation placed on public authorities annually to monitor and publicise the ethnic composition of their own workforce, thereby highlighting racial inequality in employment as part of the Amendment Act's 'agenda'. In effect, the Act means that public authorities have a duty to ensure contractors do not discriminate.

Yet the guidance supporting the Act, published by the CRE but which required Home Office approval (Commission for Racial Equality, 2002), falls far short of advising public authorities to adopt the form of contract compliance that has taken place with the West Midlands Common Standard. Instead, the guidance actually understates the legal position, advising that contractors should only be encouraged to have an EOP on a voluntary basis and only when a contract has been awarded:

As well as writing performance standards for delivering a service into a contract, you may be able to use your procurement function to promote race equality by encouraging your contractors to draw up policies that will help them to avoid unlawful racial discrimination, and promote equal opportunities. This should only be on a voluntary basis and you should only discuss the question of a contractor adopting an equal opportunities policy (if they do not already have one) when the contract has been awarded. (ibid: 68, emphasis added) 
Rather than a ringing endorsement of the use of contract compliance and a significant change in policy direction, the guidance appears to suggest even less than is permitted under the 1988 Act and the six questions. This looks more like a step backwards rather than forwards. The CRE has recently responded by publishing further guidance for public authorities (Commission for Racial Equality, 2003).

\section{Making sense of New Labour policy on contract compliance}

New Labour is often characterised in terms of 'ambiguity', 'tension' and 'contradiction' (for example, see Lister, 2001; Clarke, 2004) so in this final section we will try to make some sense of the specific ambiguity we have identified regarding contract compliance. We will consider three possible explanations: (i) that there is a more general tension within New Labour's approach to racial equality; (ii) there is a fundamental tension between the use of contract compliance to promote social objectives and a concern with fiscal restraint and control of public spending; and (iii) the importance of New Labour's commitment to labour market flexibility.

Looking beyond contract compliance, New Labour policy development on 'race' and racism can be seen to have 'two very different faces' (Back et al., 2002: 446). For example, New Labour has taken a significant step in placing institutional racism on the political agenda, particularly in response to the report of the inquiry into the murder of the black teenager, Stephen Lawrence (Macpherson, 1999), and, as discussed above, it has placed on public authorities a statutory duty to promote racial equality through the $\mathrm{RR}(\mathrm{A}) \mathrm{A}$. But, at the same time, the development of punitive immigration legislation demonstrates New Labour's strategic attempts to delineate and separate issues of 'race' (Neal, 2003). Indeed, Back et al. (2002: 453 ) conclude that, in relation to racial equality, 'the Blair government is a political formation riddled with incommensurable commitments and aspirations'. This would certainly appear to explain New Labour ambiguity at a general level, although it does not necessarily explain tensions in the specific policy area of contract compliance. For this, we need to consider other issues.

A further possible explanation is Fee's (2002: 111) argument that the use of contract compliance raises basic political and ideological questions about the pursuit of social objectives 'versus the central value for money principle of New Public Management'. We have seen that the Cabinet Office Final Report and the Byatt Report both explicitly state that increased cost and a threat to efficiency are reasons to be wary of the use of contract compliance. Best Value certainly does not mean that cost is no longer an issue and, with New Labour, control of public expenditure has continued to be a major priority, not least in relation to local government (Rao, 2000). Thus, contract compliance may be acknowledged as a means of pursuing racial equality in employment, but this is subordinate to the 
control of public expenditure. The room for policy development on equalities is immediately restrained by this over-riding priority.

The third explanation is based on New Labour's commitment to labour market flexibility. New Labour is committed to maintaining the most lightly regulated labour market of any leading economy (Dean, 2002a). The importance of this commitment can be seen in a number of policy arenas. Dean (2002b) argues, for example, that in relation to policy development on the worklife balance, making it possible for parents to combine paid employment and family life means adopting an approach to labour market policy that places unequivocal social obligations on business. But the government's position is that to legislate for flexible working practices might undermine best practice and stifle innovation. The outcome is a legal right to request, but not necessarily achieve, flexible working and it is hard to avoid the conclusion that the government is inclined to put the interests of business above the needs of low-income families' (ibid: 9). Similarly, there has been considerable government policy development on gender inequality in the labour market, especially in relation to the gender pay gap (see Kingsmill, 2001; Dench et al., 2002; Women and Equality Unit, 2002). New Labour did commit itself to undertaking pay reviews in government departments, but with the private sector the emphasis remains heavily on encouraging and persuading, not requiring, employers to adopt equality practices. Progress has been slow, and data show the pay gap widened slightly in 2002 (Equal Opportunities Commission, 2003).

Within this philosophical ambiguity surrounding 'race' and racism, New Labour's emphasis on the control of public spending, and the priority given to labour market flexibility, tensions regarding contract compliance are perhaps not surprising. Implicit in New Labour's policy development on equalities' issues is a rejection of the argument that the free market will automatically promote equality as is claimed by neo-liberals (for example, Barry, 1990). But, at the same time, New Labour has not abandoned neo-liberal economic policies. So, the scope for discussion of equalities' issues is certainly greater than in the 1980 and this in turn gives rise to greater consideration of contract compliance. Our argument is that there appears to be a hierarchy of policy development under New Labour. Policy development on equalities must take place within the context of a primary commitment to labour market flexibility and control of public spending, and the room for developing action to confront inequality is constrained. When policy development threatens (say) to encroach upon labour market flexibility then the restricted scope becomes apparent. The tensions and ambiguities we have identified regarding contract compliance do not necessarily reflect a contradiction on the part of New Labour. Rather, when looking at other policy areas such as work-life balance and the gender pay gap, what is apparent is a consistent professed aspiration for social change, but subject to the constraints imposed by a dominant commitment to the maintenance of neo-liberal economic 
policies. As Clarke (2004: 42) argues, the difficulty is not noticing that different tendencies are at play in New Labour, but grasping how they are 'structured in dominance'; thus, while some subordinate elements of New Labour are different from those of the New Right of the 1980s and 1990s, New Labour remains a neo-liberal dominated alliance.

\section{Conclusion}

Jessop (2002) argues that under New Labour there has been a 'routinisation' of neo-liberal economics. In the first part of this article we presented findings indicating the successful use of contract compliance to ensure employers formulate, and implement, an equal opportunities policy. In the second part of the article we identified ambiguity surrounding New Labour's policy development with regard to contract compliance, based on a tension between evidence demonstrating that contract compliance is an effective means of redressing racial inequality in employment and the government's concern about potentially 'negative' impacts, cost appearing to be the key issue. In making sense of this ambiguity, it is New Labour's over-riding commitment to neo-liberal economic policy that appears to provide the answer. To apply Jessop's argument to contract compliance, what we have perhaps seen is the routinisation of policy development within the framework of neo-liberal economic policy.

The question all of this begs is whether New Labour will fulfil its stated commitment to end racial discrimination in employment by 2013. The evidence of the last 35 years (that is, the period during which such discrimination has been formally outlawed) gives little cause for optimism. Widespread discrimination remains stubbornly common in the absence of strong political will from central government. There is no evidence from any major western economy that merely encouraging employers not to discriminate has succeeded. As a consequence, discrimination remains the prime factor in explaining racial inequality in employment. Contract compliance offers a way forward by actually requiring (rather than simply encouraging) employers to incorporate equal opportunities as a core element of their human resource strategy. If such an approach is not adopted, and New Labour continues to share with its Conservative predecessors a profound reluctance to intervene in what are assumed to be the sovereign rights of private sector employers, then only limited progress can be expected.

\section{References}

Back, L., Keith, M., Khan, A., Shukra, K. and Solomos, J. (2002), 'New Labour's white heart: politics, multiculturalism and the return of assimilation', Political Quarterly, 73: 4, 445-54. Barry, N. (1990), 'Markets, citizenship and the welfare state: some critical reflections', in R. Plant and N. Barry (eds), Citizenship and Rights in Thatcher's Britain: Two Views, London: IEA Health and Welfare Unit.

Berthoud, R. (2002), 'Poverty and prosperity amongst Britain's ethnic minorities', Benefits, 10: 1, 3-8. 
Cabinet Office (2002), Ethnic Minorities and the Labour Market: Interim Analytical Report, London: Cabinet Office.

Cabinet Office (2003), Ethnic Minorities and the Labour Market: Final Report, London: Cabinet Office.

Clarke, J. (2004), 'Dissolving the public realm? The logics and limits of neo-liberalism', Journal of Social Policy, 33: 1, 27-48.

Commission for Racial Equality (2002), The Duty to Promote Race Equality: A Guide for Public Authorities, London: CRE.

Commission for Racial Equality (2003), Race Equality and Public Procurement: A Guide for Public Authorities and Contractors, London: CRE.

Cormack, J. and Niessen, J. (2002), 'Public procurement and anti-discrimination legislation', in I. Chopin and J. Niessen (eds), Combating Racial and Ethnic Discrimination: Taking the European Legislative Agenda Further, Brussels: Migration Policy Group.

Dean, H. (2002a), Welfare Rights and Social Policy, Harlow: Prentice Hall.

Dean, H. (2002b), 'Business versus families: whose side is New Labour on?', Social Policy and Society, 1: 1, 3-10.

Dench, S., Aston, J., Evans, C., Meager, N., Williams, M. and Willison, R. (2002), Key Indicators of Women's Position in Britain, London: DTI.

Department for Transport, Local Government and the Regions (2001a), Delivering Better Services for Citizens - A Review of Local Government Procurement in England, London: DTLR.

Department for Transport, Local Government and the Regions (2001b), Local Authority Procurement: A Research Report, London: DTLR.

Equal OpportunitiesCommission (2003), Facts About Men and Women in Great Britain 2003, Manchester: Equal Opportunities Commission.

Erridge, A. and Fee, R. (1999), 'Contract compliance: national, regional and global regimes', Policy and Politics, 27: 2, 199-216.

Erridge, A. and Mcllroy, J. (2002), 'Public procurement and supply management strategies', Public Policy and Administration, 17: 1, 52-71.

Erridge, A. and Murray, J. Gordon (1998), 'Lean supply: a strategy for Best Value in local government procurement?', Public Policy and Administration, 13: 2, 70-85.

Fee, R. (2002), 'Contract compliance: subnational and European influences in Northern Ireland', Journal of European Social Policy, 12: 2, 107-21.

Fee, R., Maxwell, P. and Erridge, A. (1998), 'Contracting for services - a double jeopardy? An analysis of contract compliance in the context of European and UK social and public procurement policy', Public Policy and Administration, 13: 1, 79-84.

Harris, L. (2000), 'Issues of fairness in recruitment processes: a case study of local government practice', Local Government Studies, 26: 1, 31-46.

Herring, C. and Collins, S. M. (1995), 'Retreat from equal opportunity? The case of affirmative action', in M. P. Smith and J. R. Feagin (eds), The Bubbling Cauldron: Race, Ethnicity and the Urban Crisis, Minneapolis: University of Minnesota Press.

Jackson, J. J. (1995), 'Race-based affirmative action: mend it or end it?', The Black Scholar, 25: 3, $30-42$.

Jenkins, R. (1989), 'Equal opportunity in the private sector: the limits of voluntarism', in R. Jenkins and J. Solomos (eds), Racism and Equal Opportunities Policies in the $1980 \mathrm{~s}$ (second edition), Cambridge: Cambridge University Press.

Jessop, B. (2002), The Future of the Capitalist State, Cambridge: Polity Press.

Jewson, N. and Mason, D. (1989), 'Monitoringequal opportunities policies: principles and practice', in R. Jenkins and J. Solomos (eds), Racism and Equal Opportunities Policies in the 1980 s (second edition), Cambridge: Cambridge University Press.

Kingsmill, D. (2001), The Kingsmill Review of Women's Pay and Employment, London: Cabinet Office, Department of Trade and Industry, and Department for Education and Skills.

Lister, R. (2001), 'New Labour: a study in ambiguity from a position of ambivalence', Critical Social Policy, 21: 4, 425-47. 
Macpherson, W. (1999), 'The Stephen Lawrence Inquiry: Report of an Inquiry by Sir William Macpherson of Cluny', Cm. 4262-I, Home Office, London.

Martin, S. and Davis, H. (2001), 'What works and for whom? The competing rationalities of "best value"', Policy and Politics, 29: 4, 465-75.

Martin, S., Hartley, K. and Cox, A. (1999), 'Public procurement directives in the European Union: a study of local authority purchasing', Public Administration, 77: 2, 387-406.

Mason, D. (2003), 'Changing patterns of ethnic disadvantage in employment', in D. Mason (ed.), Explaining Ethnic Difference: Changing Patterns of Disadvantage in Britain, Bristol: The Policy Press.

Modood, T., Berthould, R., Lakey, R., Nazroo, J., Smith, P., Virdee, S. and Beishon, S. (1997), Ethnic Minorities in Britain: Diversity and Disadvantage, London: Policy Studies Institute.

Neal, S. (2003), 'The Scarman Report, the Macpherson Report and the media: how newspapers respond to race-centred social policy interventions', Journal of Social Policy, 32: 1, 55-74.

Office of the Deputy Prime Minister (2003), 'Local Government Act 1999: Part 1 Best Value and Performance Improvement', ODPM Circular 03/2003 (March), London.

Orton, M. and Ratcliffe, P. (2003), Working for an Inclusive Britain: an Evaluation of the West Midlands Pilot Project, Sandwell: West Midlands Forum.

Orton, M. and Ratcliffe, P. (2004), 'Race, employment and contract compliance: a way forward for local authorities?', Local Economy, 19: 2, 150-8.

Osborne, R. D. (2003), 'Progressing the equality agenda in Northern Ireland', Journal of Social Policy, 32: 3, 339-6o.

Phillips, A. (1999), Which Equalities Matter?, Cambridge: Polity Press.

Pinkney, A. (1984), The Myth of Black Progress, Cambridge: Cambridge University Press.

Rao, N. (2000), Reviving Local Democracy, Bristol: The Policy Press.

Ratcliffe, P. (2004), Race, Ethnicity and Difference: Imagining the Inclusive Society, Maidenhead: Open University Press.

Runnymede Trust (2000), The Future of Multi-Ethnic Britain, London: Profile Books.

Taylor, B. R. (1991), Affirmative Action at Work: Law, Politics and Ethics, Pittsburgh: University of Pittsburgh Press.

Twomey, B. (2001), 'Labour market participation of ethnic groups', National Statistics: Labour Market Trends, 109: 1, 29-42.

Wallace, S. L. (1999), 'Minority procurement: beyond affirmative action to economic empowerment', The Review of Black Political Economy, 27: 1, 73-98.

Women and Equality Unit (2002), Individual Incomes of Men and Women 1996/97 to 2000/01: A Summary, London: National Statistics/DTI. 